"Influence of integrated reporting ratings, CEO age, and years of experience on the share price of top 106 JSE listed companies"

$\begin{array}{ll}\text { AUTHORS } & \text { Patient Rambe } \\ \text { Tonderayi B. Mangara }\end{array}$

Patient Rambe and Tonderayi B. Mangara (2016). Influence of integrated

ARTICLE INFO reporting ratings, CEO age, and years of experience on the share price of top 106 JSE listed companies. Problems and Perspectives in Management, 14(3-1), 216231. doi:10.21511/ppm.14(3-1).2016.08

DOI http://dx.doi.org/10.21511/ppm.14(3-1).2016.08

RELEASED ON Tuesday, 06 September 2016

JOURNAL

"Problems and Perspectives in Management"

FOUNDER

LLC "Consulting Publishing Company "Business Perspectives"

NUMBER OF REFERENCES

0
NUMBER OF FIGURES

0
NUMBER OF TABLES

0

C The author(s) 2023. This publication is an open access article. 
Patient Rambe (South Africa), Tonderayi B. Mangara (South Africa)

\title{
Influence of integrated reporting ratings, CEO age, and years of experience on the share price of top 106 JSE listed companies
}

\begin{abstract}
Integrated corporate reporting (ICR), which entails the process of compiling, documenting and reporting on company's resources, its ongoing relationships with key stakeholders; business models; products (services); and the impact of such products (or services) on stakeholders, society, as well as the environment to optimize company value, has generated considerable interest among top 100 Johannesburg Stock Exchange (JSE) listed companies in South Africa over the last decade. Despite the surging interest in ICR to leverage the social responsibility, transparency and public accountability of companies in the developing African countries, little is known about the combined influence of ICR and internal company resources and/ capabilities (e.g., age and experience of the Chief Executive Officer (CEO)) on the performance of South African listed companies. The main objective of this study, therefore, is to examine the impact of Integrated Reporting Ratings (IRR); the company CEO's age; and his/her years as a CEO on the share price of the company within the South African context. The top-106 JSE listed companies for the period Year-end 2014 constitute the sample for this study. Multivariate non-parametric regression is used to model the relationship between the predictor (i.e., independent) variables and the response (i.e., dependent) variable using MATLAB. The model developed in this study is, then, used to evaluate the impact of IRR; the CEO's age and years of experience as CEO on the share price of individual companies. The proposed methodology is illustrated step-by-step. The finding of the study reveal that the share price of a company tended to increase with an increase in IRR, age and years of experience of the $\mathrm{CEO}$, demonstrating that a company's established history in integrated reporting and corporate experience positively impact its performance (i.e., the share price).
\end{abstract}

Keywords: integrated corporate reporting, corporate responsibility, JSE listed companies, MATLAB. JEL Classification: G17.

\section{Introduction}

Integrated corporate reporting (ICR), which describes transcending stand-alone social, environmental, social responsibility and sustainability reporting to achieve an integration of sustainability and governance information within the same annual report (The Association of Chartered Certified Accountants, 2012), has gained considerable ground in the South African corporate reporting landscape owing to the intractable connection between the business operations, accountability to the stakeholders and broader communities affected by company operations. The surging popularity of ICR in today's corporate world is often attributed to the corporate value of understanding the overall economic, social, ethical and environmental impact of companies' operations on local communities (Institute of Directors in Southern Africa, 2009), the need to share responsibility with communities and demonstrate accountability for the decisions that companies take concerning the social, environmental and ethical outcomes of their activities (Solomon and Maroun, 2012).

More so, as literature acknowledges, with the recent turmoil that rocked the South African financial services sector as result of the global recession, it is more prudent now than ever to acknowledge that good

(C) Patient Rambe, Tonderayi B. Mangara, 2016.

Patient Rambe, Department of Business Support Studies, Central University of Technology, South Africa.

Tonderayi B. Mangara, Department of Electrical, Electronic and Computer Engineering, Faculty of Engineering and Information Technology, Central University of Technology Free State (CUT), South Africa. reporting does not necessarily equate to good corporate behavior (see King, 2014; PWC Integrated Report, 2014). In fact, good corporate governance behavior demands considerable intellectual stamina, commitment and application of the rules of fairness, sincerity, transparency and accountability, as the business deals with its own internal operations including its engagements with external stakeholders over and above good reporting. As its Quick Guide to Corporate Governance and King III clearly stipulates, the object of corporate governance rules is to improve the quality of leadership which boards are giving to their businesses, and corporate governance guidelines assist directors in understanding what good governance requires of them (Bowan Gilfillan Attorneys', n.d.). In essence, the challenge with implementing integrated corporate reporting lies in overcoming the stakeholder accountability rhetoric that is imbued in corporate sustainability reporting, and in increasing the focus on materiality; a tendency towards quantification (Solomon and Maroun, 2012), which often elides the qualitative ethical, social and environmental impact of companies' operations on local communities.

Yet, ICR informed by integrated thinking is not the sole determinant of company value and performance as managerial resources and/ capabilities such as the Chief Executive Officer (CEO)'s age, years of operation in that capacity and their forced or voluntary departures/ turnover are also deeply implicated in the firm's value and performance (see Dherment-Ferere and Renneboog, 2000; C'1merov'a, 2012; D'Ewart, 
2014). For instance, D'Ewart's (2014) study examined the effects of CEO age on firm value and revealed that CEOs promoted during their 40 s negatively influence firm value, while CEOs in older age brackets show a positive abnormal return on firm value. An inference from this finding is that the level of accumulated experience of a CEO judging from their age has a considerable impact on investors' expectations of this senior executive's capacity to create value for the company. C'imerov'a's (2012) study reports a positive relationship between a CEO's experience and firm performance, demonstrating the positive energy that task-relevant and contextual experience bring to a firm's value. With regard to CEO tenure, DhermentFerere and Renneboog (2000) observe that forced CEO resignations may be hailed favorably by the market with a small, but significantly positive abnormal return of $0.5 \%$, as market may have anticipated the forced turnover, since the abnormal return over a one-month period prior to the turnover amounts to $6 \%$.

To the extent that the firm's CEO commands considerable authority in the determination and ultimate execution of a company's vision, strategy and leadership, and in their abnormally high perks compared to an average employee, there is no doubt that their demographic traits (e.g., age and years as a CEO) influence the performance and value ratings of the company by investors and the general public. Although literature articulates the stand-alone impact of ICR on companies' value (King, 2011; Eccles, Ioannou, and Serafeim, 2012; Eccles and Serafeim, 2014; Steyn, 2014), and of CEO demographic characteristics (e.g., age, gender, experience, tenure), on corporate performance (Bhagat, Bolton and Subramanian, 2011; C'1merov'a, 2012; Khan and Vieito, 2013; Ayed, 2014; Serfling, 2013), what remains under-explored and unclear is the combined influence of ICR and CEO's demographic characteristics (especially age and his/her years as CEO) on the performance (especially the share price) of companies.

\section{Problem statement}

Integrated corporate reporting (ICR) is conceived to be imbued with considerable benefits to the company. By providing a competitive advantage, reducing risk levels or contributing to reputational benefits, effective ICR is considered to contribute positively to the value of particular organizations (Hassel, Nilsson \& Nyquist, 2005). In spite of this popular claim, the literature on the impact of ICR on company performance is inconclusive. For instance, in contrast with other findings which predict a positive relationship between levels of corporate social responsibility disclosures and company share prices (Carroll \& Shabana, 2010; De Klerk \& De Villiers, 2012), Marcia, Maroun and
Callaghan (2015) found no significant association between such disclosures and the company's share price. In addition, to their distinct focus on ICR, these studies tend to negate CEO demographic traits (e.g., age, years as CEO compensation) which are at the heart of explaining share price fluctuations.

Other parallel studies have also concentrated on the influence of CEO characteristics (e.g., their compensation) on their corporate power (Nulla, 2013), on firm performance (Deysel \& Kruger, 2015) to the exclusion of ICR. For instance, Nulla's (2013) corelations of CEO cash compensation (salary, bonus, shares outstanding, CEO shares value) and CEO power in American Companies were found to range from weak negative to weak positive ratios. This suggests that compensation may not, in all cases, necessarily translate into increased corporate power for the CEO. Deysel and Kruger's (2015) exploratory study sought to determine whether a long-term correlation between South African CEOs' compensation and company performance exists in the banking sector. Their study established a long-term correlation between CEO compensation and variables such as company performance, average employee salary, general market performance and inflation. It is clear that the aforementioned studies on CEO demographics are silent about the impact of the company's social responsibility to internal and external stakeholders, especially ICR on its performance.

Even though Vintilă and Gherghina's (2012) study attempted to bridge the corporate responsibility-firm performance relationship, on the one hand, and the CEO demographic characteristics-performance relationship by exploring the combined influence of corporate governance mechanisms, CEO characteristics and the performance of US listed companies, the study did not necessarily focus on integrated corporate reporting per se. More so, the findings on American companies may not resonate well with those of emerging developing countries such as that of South Africa, due to different situated contexts of prevailing corporate reporting legislation, macro-economic conditions and governance climate. In view of the foregoing discussion, it is clear that remains to be established is the combined influence of ICR and CEO demographic traits (age, and years as $\mathrm{CEO}$ ) on the performance (especially the share price) of listed companies in developing economies, a research gap this study attempts to close.

\section{Research question}

In view of the issues articulated above, we wondered about the combined influence of integrated reporting ratings (IRR); the company CEO's age; and years of experience as CEO on the performance (especially the 
share price) of the company within the South African context. The study, therefore, explored the following research question:

What is the combined influence of IRR, CEO's age and years of experience on the share price of the top106 Johannesburg Stock Exchange (JSE) listed companies for the period Year-end 2014?

\section{Problem background}

The South African legal framework of corporate governance

In the South African context, the landmark policy documents that laid the foundation for corporate governance in general, stakeholder accountability and integrated corporate reporting in line with global standards in particular, are: the King Report I (1994), King Report II (2002) and King Report III (2009). Following the constitution of the Mervin King Committee on Corporate Governance in South Africa in 1992, the ultimate consequences of its broad consultations and deliberations were the development of corporate governance and integrated reporting guidelines, consistent with international standards, through the King I Report in 1994. As the South African Institute of Chartered Accountants (2009) observes, the King Report 1994, which institutionalized corporate governance in South Africa, aimed to establish some recommended standards of conduct for boards and directors of listed companies, banks, and certain state-owned enterprises. For the first time in South Africa, the need for companies to take responsibility for their operations in relation to the societies that they serve was brought into sharp focus. In addition to the financial and regulatory aspects of corporate governance, King I advocated an integrated approach to good governance in the interests of a wide range of stakeholders (Dekker Attorneys, 2002) and encouraged the practice of good financial, social, ethical and environmental practices (South African Institute of Chartered Accountants, 2009). Although it was considered to be ground breaking since no country on the African continent had attempted such a practice at that time, the forces of change in corporate reporting globally and new legislative developments, have necessitated the updating of King I (Dekker Attorneys, 2002).

With a strong emphasis on stakeholder-oriented corporate governance, King II Report (2002) suggested a further integration of sustainability into governance and reporting by requiring businesses to embed social, environmental and governance considerations into the heart of their operations (Solomon and Maroun, 2012). The apparent shift from the single bottom line (that is, profit for shareholders) to a triple bottom line, which embraces the economic, environmental and social aspects of a company's activities (Dekker Attorneys, 2002) is self-evident in King II Report's call for companies to embrace institutional activism through greater emphasis on the sustainable or non-financial aspects of their performance (King II Report, 2002). The same Report requires Boards to apply the test of fairness, accountability, responsibility and transparency to all their acts or omissions, to increase their accountability to the company, as well as their responsiveness and responsibility towards their identified stakeholders (The King Committee, cited in Dekker Attorneys, 2002).

The challenge of applying King II Report's code and practices was the compulsive element in the language discourses of this report, which could potentially trigger relentless and uncritical application of codes, ethics and practices of the Report. As the Gilfillan Attorneys (2009) argues, a "comply or explain" approach could denote a mindless response to the Code and its recommendations, whereas the 'apply or explain' regime demonstrates an appreciation of the fact that, it is often not a case of whether to comply or not, but rather to consider how the principles and recommendations of the Code can be applied. Since integrated corporate reports are available to the company stakeholders to ascertain the extent of application of integrated thinking, the stakeholders themselves are best positioned to establish the level of compliance and evaluate the company's depth of understanding of the meaning and significance of such integrated thinking.

The first national attempt to enforce integrated reporting across all listed companies was, however, introduced in 2010 by the Johannesburg Stock Exchange (JSE), which mandated integrated reporting through its listing requirements via compliance with the King III Report 2009 (Solomon and Maroun, 2012). The King III, which was necessitated by the introduction of the new Companies Act in 2008 including some shifts in international trends on corporate reporting and governance, comprises the King Report on Governance for South Africa 2009 ("the Report"), the King Code of Governance Principles for South Africa 2009 ("the Code") and Practice Notes to King III issued by the Institute of Directors, which guide the implementation of the Code (Bowan Gilfillan Attorneys' Quick Guide to Corporate Governance and King III, n.d.). At the core of the King III Report is an ostensible shift from the 'comply or explain' approach adopted by King II Report, towards an 'apply or explain' approach to corporate governance, even though it continues to follow a voluntary basis for governance compliance (Bowan Gilfillan Attorneys' Quick Guide to Corporate Governance and King III, n.d.). It can be inferred from this that, although companies are encouraged to apply 
corporate governance principles in their business operations, the King III now exerts considerable pressure on companies to demonstrate the practical application of such integrated thinking and reporting or at least illustrate the effectiveness of such application.

\section{Literature review}

4.1. Integrated corporate reporting: an overview. Hudson, Jeaneau and Zlotnicka (2012) conceive integrated corporate reporting (ICR) as a true and fair view [of the company], incorporating all information relevant to its core business [financial investment, strategy and sustainability issues], readily comparable with peers, and providing insight into potential tail risk. It transcends sustainability reporting by embracing financial and non-financial reporting, sustainability issues, multiple stakeholders relationships (investors, regulators, NGOs and customers) and the interdependencies of resources and capabilities (financial, human, material and environmental) and the information that gives rise to them all. It, therefore, captures a company's integrated explanation of how it creates value for its investors and shareholders, and appeals to the capital markets through its description of how financial and nonfinancial resources can be harnessed in the short to long term. To the extent that ICR puts greater emphasis on information about the future, it assists investors in assessing the organization's ability to generate future cash flows (IIRC, 2011).

Overall, ICR renders financial and non-financial information of a company's strategy, performance and governance in its business and social context, in a way that highlights the interdependencies of the information (KPMG International Cooperative, 2011). At the core of ICR, therefore, are the:

- advancement of strategic decision making that takes due cognizance of the organization's dependence on resources and business/social relationships in creating and sustaining longerterm stakeholder value;

- greater recognition of the linkages and interdependencies between financial, social and environmental, and economic matters in setting strategic objectives;

- increased organizational focus on integrating social and environmental objectives into strategic objectives; and

- aligning reported key performance indicators (KPIs) with external stakeholder requirements (Steyn, 2014).

4.2. The benefits of integrated corporate reporting. For Eccles and Serafeim (2014), the benefits of ICR are that: (1) it potentially generates better information, which empowers individuals and organizations to participate in economic transactions and deepen the liquidity of markets; and (2) incorporation of such information in the decision making process of economic agents yields price signals that accurately reflect individual preferences. The successful decision making from ICR, however, resides in transcending the perfect organization and presentation of company information (i.e., good reporting) towards embracing and entrenching the spirit of corporate accountability, integrity, and transparency so that external stakeholders can effectively contribute to and have a stake in improving the sustained corporate value of the organization. Eccles, Ioannou, and Serafeim (2012) compared the effect of corporate sustainability on the organizational processes and performance of high sustainability US companies (that is, companies that voluntarily adopted sustainability policies from 1993 to 2009) and low sustainability companies (that is, firms that adopted almost none of these policies). Among other considerations, high sustainability companies were more likely to have well established processes for stakeholder engagement, to be more long-term oriented, and exhibit higher disclosure of non-financial information than low sustainability companies. More so, high sustainability companies significantly outperformed their counterparts over the long-term, both in terms of stock market, as well as accounting performance. It can be inferred that companies that display high ICR are more placed than their counterparts to generate public trust and accountability in their activities, trigger a positive image of their corporate activities to the outside world in ways that impact on their performance positively.

At the core of ICR is the management of a company's strategy, routine operations and the propping of their brands. As King (2011) aptly observes, integrated reporting equips companies to manage their operations, brand and reputation strategically and to manage better any risks that may compromise the long-term sustainability of the business. The external visibility and credibility of the organization are at the heart of a well-oiled ICR machine as such a sustainability report positions the organization at a vantage point corporate-wise to determine niche areas it should seek to maximize value in and commitments it should savour ties. The International Integrated Reporting Committee (IIRC) reiterates that ICR visualises and makes visible an organization's use of and dependence on different resources and relationships or "capitals" (financial, manufactured, human, intellectual, natural and social), the organization's access to and impact on them. As such, ICR: (1) affords a meaningful assessment of the longterm viability of the organization's business model and strategy; (2) ensures the meeting of information needs of investors and other stakeholders; and (3) allows the effective allocation of scarce resources (IIRC, 2011). 
All the above implies that ICR allows more prudent resource allocation including the reduction of costs in non-critical areas, a more intensive collective engagement with stakeholders, cheaper access to capital acquisition and a reduction in external risks due to increased disclosures.

\subsection{Challenges of integrated corporate reporting.} The challenges of implementing and making ICR a global enterprise are tied both to organizational capacities, national stock exchanges, as much as they relate to the stakeholders implicated in the process. From an organizational perspective, King (2014) highlights that one of the chief inhibitors of progress in integrated reporting quality is a distinct lack of integrated thinking within many organizations. Other capacity constraints revolve around commercial confidentiality, that is, organizations may not always have the capacity to distinguish information not currently subject to mandatory disclosure requirements in their Integrated Reports and, hence, struggle to balance disclosure with the desire to avoid disclosing competitive information (IIRC, 2011). More so, since the loci and foci of ICR spans multiple new and evolving subjects, with a strong future orientation, concerns about the liability of governance regime of companies will need to be addressed (IIRC, 2011). Moreover, the strong future orientation of ICR may compromize an organization's ability to attend to the short-term investments and capital flows, itself the main concerns of investors.

From a national stock market perspective, despite the popularity of ICR, its wider scale impact has not been felt and making ICR compulsory may contribute to universalizing ICR. Making integrated corporate reporting a requirement or making it a core component of capital allocation to companies, may bring environmental performance accounting to the mainstream, since such accountability would no longer be a subservient supplement to the main financial accounts (Burritt, 2012). From stakeholder perspective, ICR many not thrive where growing mistrust brews between the organization and its stakeholders. The disconnection of employees, customers and stakeholders from the companies they engage with has triggered phenomenal public distrust of business (Sisodia, 2009) raising perplexing questions about the feasibility of universalizing ICR across sectors and industries.

4.4. CEO demographics and share price. Serfling (2013) predicts that risk-taking behavior of a CEO decreases as he/she gets older, with negative implications on stock return volatility. This means that older CEOs tend to be less daring to engage in risky investment ventures than younger ones. His study elaborates that older CEOs invest less in research and development, maintain lower operating leverage and make more diversifying acquisitions than younger ones (Serfling, 2013). Bhagat, Bolton, and Subramanian (2011) support the view that CEO characteristics such as age, tenure and stock ownership positively affect firm performance. A multivariate regression analysis, however, needs to be performed to establish how the combined influence of independent variables affect the dependent variable.

Smith, Smith and Verner's (2005) panel study examined the impact of women in top management on the performance of 2500 Danish firms. The 1993 to 2001 data set revealed that a considerable proportion of women in top management jobs tend to have positive effect on firm performance, even after controlling for numerous firm characteristics and direction of causality. Khan and Vieito's (2013) panel study of US firms (1992 to 2004) evaluated whether firms managed by female CEOs exhibit the same performance as firms managed by male CEOs including whether CEO's gender affects the risk level of the firm. The results demonstrate that on average, the gender of the CEO matters in terms of firm performance, and that where the CEO is a female, the firm risk level is smaller than when the CEO is a male. Yet, this female risk averseness does not illuminate our understanding of the possible impact of CEO demographics on firm performance if ICR was compounded to this relationship.

Allgood and Farrell (2000) explored the relationship between CEO tenure, firm performance-turnover and revealed that the performance-forced turnover relation is conditional on CEO tenure, and there exists a constant negative relationship between firm performance and forced turnover. Dikolli, Mayew and Nanda (2011) examined the influence of CEO tenure on firm performance-turnover relationship. They report that the negative relation between CEO turnover and firm performance declines with CEO tenure. This finding reflects firm performance's capacity to reveal information about a CEO's uncertain ability to create firm value, as well as the capacity of CEO tenure to reflect a CEO's entrenched power, thereby reducing the likelihood of performance-related dismissal. These findings, however, do not shed light on the implication of tenure on performance if sustainability reporting variable was implicated in the relationship. Ayed (2014) examined the relationship between CEO characteristics (CEO optimism, seniority and discretionary accruals) and financial performance of French firms characterized by a high degree of concentration of ownership. The results demonstrate that managerial optimism can decrease the firm's performance, while discretionary accruals are found to be positively associated with firm performance. The findings of the study also contradicted the view that an increase in CEO discretion has a negative influence on 
performance insofar, as it can lead to decisions contrary to the interests of shares. Yet, the combined influence of company resources and /capabilities (e.g., CEO characteristics) and ICR on the share price of a company are still to be investigated rigorously.

C'imerov'a's (2012) research examined the influence of CEO experience and education on firm performance, variability of firm performance, investment and financing policies, as well as organizational strategy. The findings suggest that it is not only the choice of CEO to match company needs that positively impacts firm performance, but also their duration as CEO. The CEO's industry and experience was also deemed to positively influence firm outcomes and policies, especially firm performance, variability of firm performance and investment policy. However, the combined influence of integrated corporate reporting and CEO demographic characteristics on firm performance, especially the share price of the company is, yet, to be fully understood. Even through Vintilă and Gherghina's (2012) study attempted to bridge that corporate responsibility-firm performance on one hand, and the CEO demographic characteristics-performance gap by exploring the combined influence of corporate governance mechanisms, CEO characteristics and the performance of US listed companies, the study did not necessarily focus on integrated corporate reporting in particular. More so, the findings on American companies may not resonate well with those of emerging developing countries such as that of South Africa.

\section{Methodology}

To the effect that the fragmented literature on integrated corporate reporting (ICR), CEO age and CEO's years of experience's relationships with firm performance has examined each of these relationships independently, and has not necessarily targeted the combined effect of ICR, CEO's age and years of experience on performance, there is uncertainty about the integrated effect of these variables on the performance of firms (especially share price) in emerging economies. The current study, therefore, sought to close this gap by examining the integrated influence of these independent variables (ICR, CEO age and years of experience as $\mathrm{CEO}$ ) on the share price of JSE listed companies.

The predictor (i.e., independent) variables data, are Integrated Reporting Ratings (IRR); the Chief Executive Officer's age; and years of experience as CEO of top-106 Johannesburg Stock Exchange (JSE) listed companies. The response (i.e., dependent) variable data, is the share price of top-106 JSE listed companies. Exploratory data analysis is used to model the relationship between the predictor and the response variables. Exploratory data analysis involves graphical "detective" work (Tukey, 1977), in which the researcher examines the data without any preconceived notions to uncover the rich insights emerging in the data about the phenomena under study. Since the relationships between the predictor and response variables cannot be determined in advance, with regard to whether they are linear, colinear or non-linear, exploratory data analysis is ideal for unravelling such relationships.

The researchers plotted the data and employed a curve fitting MATLAB to model the relationship. Since the researchers could not determine in advance the model to use, they adopted a non-parametric approach, where a more general model was employed. The model is given by:

$Y=\sum_{j=1}^{d} f\left(X_{j}\right)+\in$

Here, each $f\left(X_{j}\right)$ will be a smooth function and allows for non-linear functions of the dependent variables. In this study, the researchers' attention was drawn to the case where only four variables: three predictor and one response variables were available. Thus, the researchers built a piecewise-cubic non-parametric regression model (with ARESLab - a MATLAB/Octave toolbox) using the Multivariate Adaptive Regression Splines method (also known as MARS). The term "MARS" is a registered trademark and hence is not used in the name of the toolbox. Jerome Friedman is the author of the MARS method (Friedman, 1991, 1993).

Using MATLAB/Octave toolbox, the researchers built a model for a single-response and multi-predictor data set, tested the model using cross-validation, tested the model using test data, used the model for prediction, printed their equation, performed an analysis of variance (ANOVA) decomposition, assessed input variable importance, as well as plotted the model.

\subsection{MATLAB Printed model equation.}

$y=1.66 \mathrm{e}+06+5.37 \mathrm{e}+03 * \mathrm{BF} 1-6.59 \mathrm{e}+$
$+03 * \mathrm{BF} 2+7.35 \mathrm{e}+03 * \mathrm{BF} 3+2.77 \mathrm{e}+$
$+04 * \mathrm{BF} 4+4.22 \mathrm{e}+04 * \mathrm{BF} 5-1.1 \mathrm{e}+$
$+04 * \mathrm{BF} 6+677 * \mathrm{BF} 7-1.42 \mathrm{e}+$
$+03 * \mathrm{BF}+7.91 \mathrm{e}+04 * \mathrm{BF}-1.76 \mathrm{e}+03 * \mathrm{BF} 10-$
$-2.56 \mathrm{e}+03 * \mathrm{BF} 11-377 * \mathrm{BF} 12+2.59 \mathrm{e}+$
$+04 * \mathrm{BF} 13-3.22 \mathrm{e}+03 * \mathrm{BF} 14-1.11 \mathrm{e}+04 * \mathrm{BF} 15-$
$-4.93 \mathrm{e}+04 * \mathrm{BF} 16+3.16 \mathrm{e}+04 * \mathrm{BF} 17+$
$+351 * \mathrm{BF} 18+4.15 \mathrm{e}+03 * \mathrm{BF} 19-1.47 \mathrm{e}+$
$+04 * \mathrm{BF} 20+4.39 \mathrm{e}+03 * \mathrm{BF} 21+7.42 \mathrm{e}+04 * \mathrm{BF} 22-$
$-1.58 \mathrm{e}+03 * \mathrm{BF} 23-8.12 \mathrm{e}+03 * \mathrm{BF} 24+$
$+4.91 \mathrm{e}+03 * \mathrm{BF} 25-1.79 \mathrm{e}+03 * \mathrm{BF} 26+$
$+1.72 \mathrm{e}+03 * \mathrm{BF} 27+8.99 \mathrm{e}+03 * \mathrm{BF} 28-$
$-9.01 \mathrm{e}+03 * \mathrm{BF} 29+554 * \mathrm{BF} 30+121 * \mathrm{BF} 31-$
$-280 * \mathrm{BF} 32-242 * \mathrm{BF} 33+216 * \mathrm{BF} 34+$
$+9.36 \mathrm{e}+03 * \mathrm{BF} 35-9.58 \mathrm{e}+03 * \mathrm{BF} 36+$


$+377 * \mathrm{BF} 37+225 * \mathrm{BF} 38-207 * \mathrm{BF} 39+$

$+32.7 * \mathrm{BF} 40+31.6 * \mathrm{BF} 41-96.2 * \mathrm{BF} 42+$

$+8.46 \mathrm{e}+03 * \mathrm{BF} 43+2.31 \mathrm{e}+03 * \mathrm{BF} 44+$

$+690 * \mathrm{BF} 45+13.8 * \mathrm{BF} 46+159 * \mathrm{BF} 47-$

$-933 * \mathrm{BF} 48+315 * \mathrm{BF} 49+40.7 * \mathrm{BF} 50+$

$+338 * \mathrm{BF} 51+6.56 \mathrm{e}+03 * \mathrm{BF} 52+3.51 * \mathrm{BF} 53-$

$-62.2 *$ BF54 $+5.83 \mathrm{e}+03 *$ BF55 - 6.24e +

$+03 * \mathrm{BF} 56+396 * \mathrm{BF} 57-389 * \mathrm{BF} 58-$

$-4.9 \mathrm{e}+03 *$ BF59 $+1.12 \mathrm{e}+05 * \mathrm{BF} 60-$

$-1.09 \mathrm{e}+05^{*} \mathrm{BF} 61+1.62 \mathrm{e}+04 * \mathrm{BF} 62-$

$-1.23 \mathrm{e}+04 * \mathrm{BF} 63-674 * \mathrm{BF} 64+360 * \mathrm{BF} 65+$

$+255 * \mathrm{BF} 66-224 * \mathrm{BF} 67+963 * \mathrm{BF} 68-$

$-311 * \mathrm{BF} 69-7.92 \mathrm{e}+03 * \mathrm{BF} 70+$

$+290 * \mathrm{BF} 71+506 * \mathrm{BF} 72$.

ANOVA decomposition:

$\begin{array}{ll}\text { Function } & \text { STD } \\ 1 & 698672.638553174053710 .053213 \\ 2 & 779279.606491142443354 .595585 \\ 3 & 779640.337049139699051 .886653 \\ 4 & 423032.131791166469176 .711111 \\ 5 & 802477.963000143218137 .509673 \\ 6 & 2013798.474454256619298 .030959 \\ 7 & 571704.973551194760120 .568218\end{array}$

Relative variable importance:

$\begin{array}{lc}\text { Variable } & \text { Importance } \\ 1 & 99.517 \\ 2 & 100.000 \\ 3 & 95.835\end{array}$

An ANOVA decomposition and assessment of variable importance on the MATLAB command is shown above. The second decomposition table illustrates that variable 1 (Integrated Report Ratings) has a relative importance of $99.52 \%$, variable 2 (CEO's age) has a relative importance of $100 \%$ and variable 3 (years as CEO) has that of $95.84 \%$.

\subsection{Test of the model using test data.}

$>>$ arestest(model, XX, YY)

ans $=$

MAE: $2.83887739682559 \mathrm{e}+003$

MSE: $14.9787373253654 \mathrm{e}+006$

RMSE: $3.87023737325831 \mathrm{e}+003$

RRMSE: 218.867698786222e-003

R2: 952.096930428024e-003
The model equation printed by MATLAB is illustrated above and the data set has only three input variables. Hence, the researchers used the equation's first three variables as follows: $y=1.66 \mathrm{e}+06+$ $+5.37 \mathrm{e}+03 * \mathrm{BF} 1-6.59 \mathrm{e}+03 * \mathrm{BF} 2+$ $+7.35 \mathrm{e}+03 * \mathrm{BF} 3$.

\subsection{Assessment of input variable importance.}

$>$ aresanova(model, XX, YY)

Type: piecewise-cubic; GCV: $1.54546 \mathrm{e}+08$

R2GCV: 0.505749

Total number of basis functions: 73 .

Total effective number of parameters: 73 .

\begin{tabular}{|c|c|c|c|}
\hline R2GCV & & \#basis \#params & variable(s) \\
\hline 0.4434 & 3 & 3.00 & 1 \\
\hline 0.5445 & 2 & 2.00 & 2 \\
\hline 0.5532 & 3 & 3.00 & 3 \\
\hline 0.4676 & 6 & 6.00 & 12 \\
\hline 0.5420 & 9 & 9.00 & 13 \\
\hline 0.1793 & 16 & 16.00 & 23 \\
\hline 0.3771 & 33 & 33.00 & 23 \\
\hline
\end{tabular}

Testing the model using the test data shown above reveals that $\mathrm{R}^{2}$ is $952.096930428024 \mathrm{e}-003$. This means that the value of $\mathrm{R}^{2}$ is $95.2 \%$ and it indicates that the regression model is able to explain over $95.2 \%$ of the variation in the share price. This means that the model equation is a good fit of the data set in Appendix A.

5.4. Choice of non-parametric regression. The purpose of a normal probability plot is to graphically assess whether the data in the predictor (independent) variables, that is, Integrated Reporting Ratings; the CEO's age; and years as CEO (see Appendix A) could come from a normal distribution. If the data are normal, the plot will be linear and multivariate linear regression can be used. Fig. 1 to Fig. 3 indicate that the data do not follow a normal distribution and, therefore, multivariate non-parametric regression was used in this study.

5.5. Challenges. Two common challenges in creating an accurate curve fit are: the researchers; 1) cannot describe and predict the relationship between the predictor and response variables in advance (not a priori knowledge); and 2) cannot specify good starting points for the MATLAB solvers. 


\section{Results}

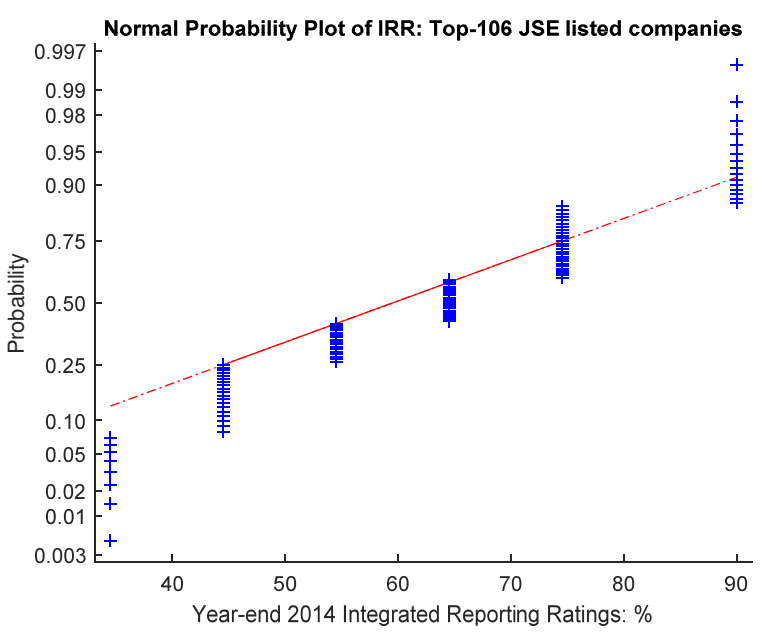

Fig. 1. Normal Probability Plot of IRR for top-106 JSE listed companies

The normal probability plot of IRR for top-106 JSE listed companies illustrates that the data are not normal. Therefore, one cannot use linear regression analysis, but rather non-parametric regression analysis should be used to determine the influence of IRR on the share price.

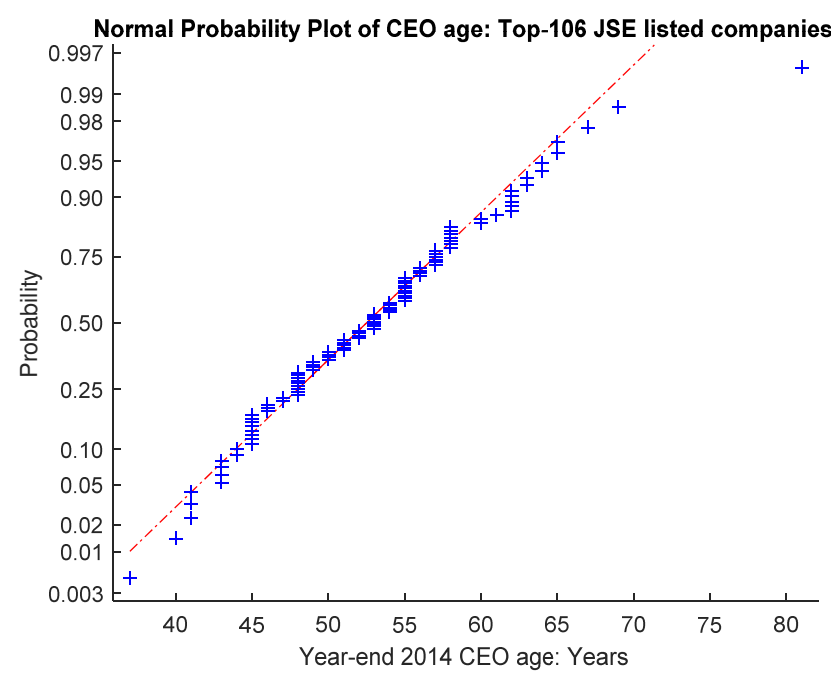

Fig. 2. Normal Probability Plot of CEO age for top-106 JSE listed companies

The normal probability plot of CEO age for top-106 JSE listed companies demonstrates that the data are not normal. Therefore, one cannot use linear regression analysis, but rather non-parametric regression analysis should be used to determine the influence of CEO age on the share price.

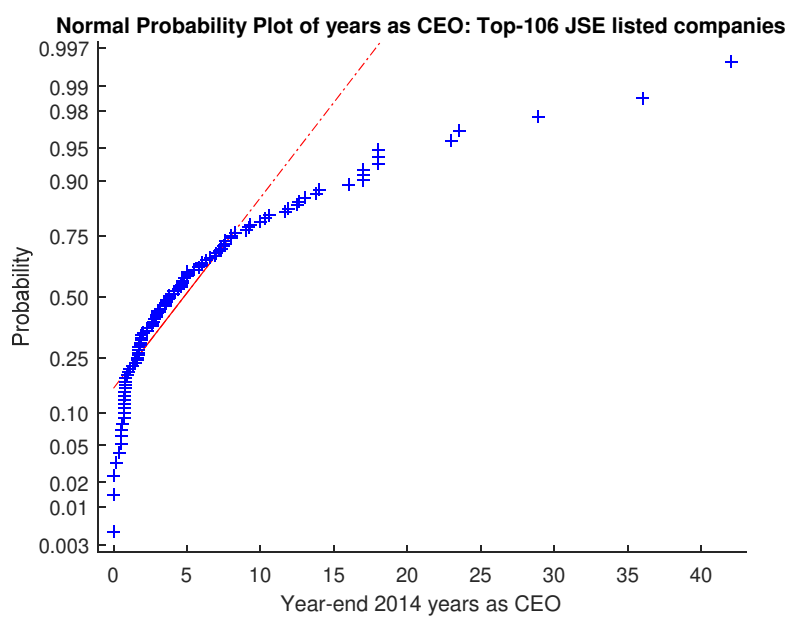

Fig. 3. Normal Probability Plot of years as CEO for top-106 JSE listed companies 
The normal probability plot of years as CEO for top106 JSE listed companies illustrates that the data are not normal. Therefore, linear regression analysis is not applicable, but rather non-parametric regression analysis should be used to determine the influence of years as CEO on the share price.

6.1. Model cross-validation: using crossvalidation to select the number of basis functions. For the data set in Appendix A, the researchers employed a 10 -fold cross-validation and repeated cross-validation several times (ten in their case) to generate more stable results. The MATLAB code used is as follows:

$\operatorname{rng}(1)$;

results_validation $=\operatorname{arescv}(\mathrm{XX}, \mathrm{YY}$, params $)$;

$[\sim, \sim$, resultsPruning $]=\operatorname{arescv}(\mathrm{X}, \mathrm{Y}$, params, 10, [], [10], [], [], true);

\subsection{Cross-validation results.}

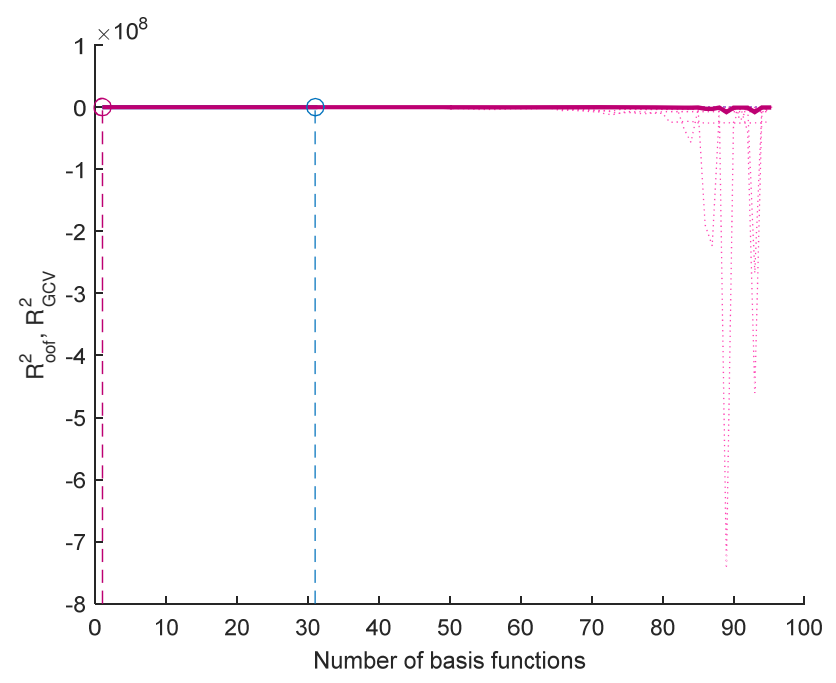

Fig. 4. Plot of cross-validation results

The blue dotted lines show the $\mathrm{R}_{\mathrm{GCV}}^{2}\left(\mathrm{R}^{2}\right.$ estimated using Generalized cross-validation (GCV)) for models of each fold. The blue solid line is the mean $\mathrm{R}_{\mathrm{GCV}}^{2}$ for each model size (that is, the average of the blue dotted lines). The pink dotted lines show the out-of-fold $\mathrm{R}^{2}$ for models of each fold. The pink solid line is the mean out-of-fold R2 for each model size (i.e., the average of the pink dotted lines). The two vertical dashed lines are at the maximum of the two solid lines, showing the optimal number of terms estimated by GCV (blue) and cross-validation (pink). Ideally, the two vertical lines would coincide. In practice, they are usually close but not identical. In this case, the two lines are at 31 (for $\mathrm{R}_{\mathrm{GCV}}^{2}$ ) and 1 (for $\mathrm{R}_{\text {oof }}^{2}$ ).

\subsection{Performed Analysis of Variance (ANOVA)} decomposition - and shown through the plot of ANOVA functions. In Fig. 5 and Fig. 66, the ANOVA functions, which comprise of three input variables were plotted to allow for the visualization of the contributions of the ANOVA functions.

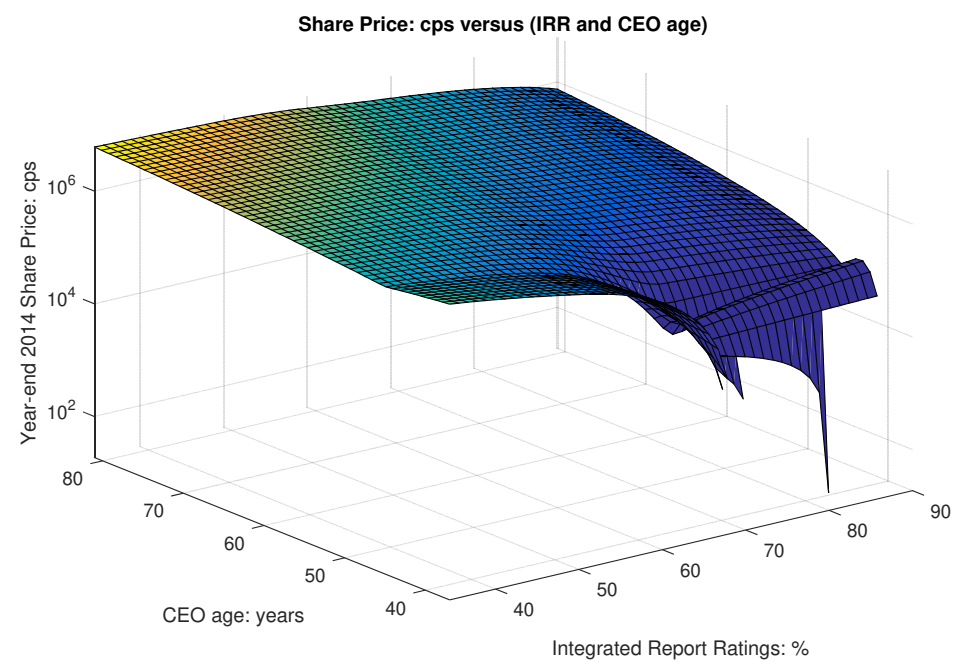

Fig. 5. ANOVA functions: Share price versus IRR and CEO age: Top-106 JSE listed companies 
Figure 5 is a plot of three ANOVA functions: single-response variable (share price) versus

pair-wise predictor variables (Integrated Report Ratings and CEO age).

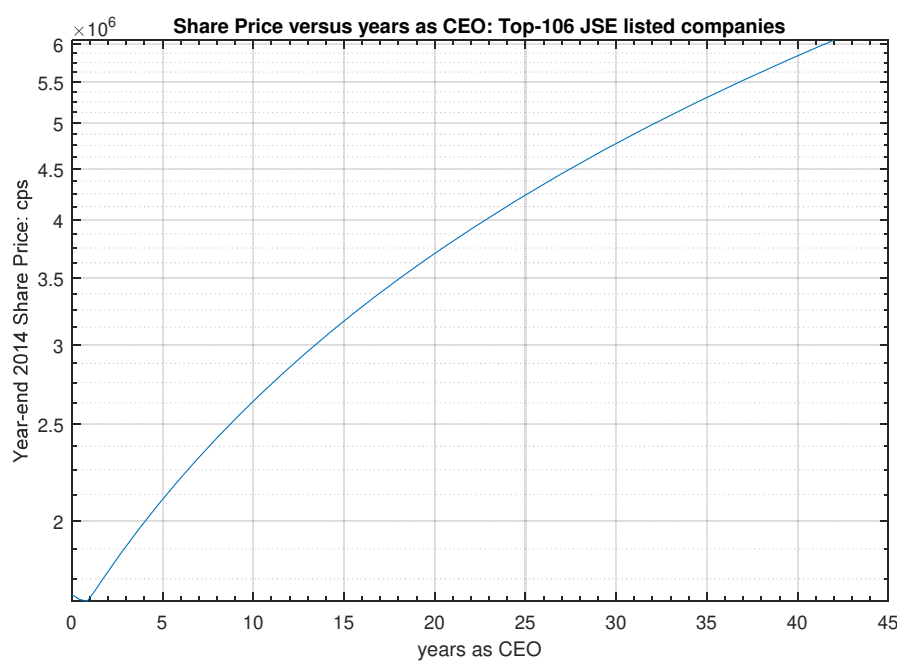

Fig. 6. ANOVA functions: Share price versus years as CEO: Top-106 JSE listed companies

Figure 6 is a plot of two ANOVA functions: single-response variable (share price) versus a single-predictor variable (years as CEO). As depicted in Figure 6, as one's years as CEO increases so does the share price. The graph, however, follows a non-linear curve and also shows that the companies with CEOs with the highest numbers of years as CEO, have the highest share price.

6.4. Developed model. Fig. 7 shows the plot of the model using the first two variables, while values for all the other variables are fixed at the middle of their ranges.

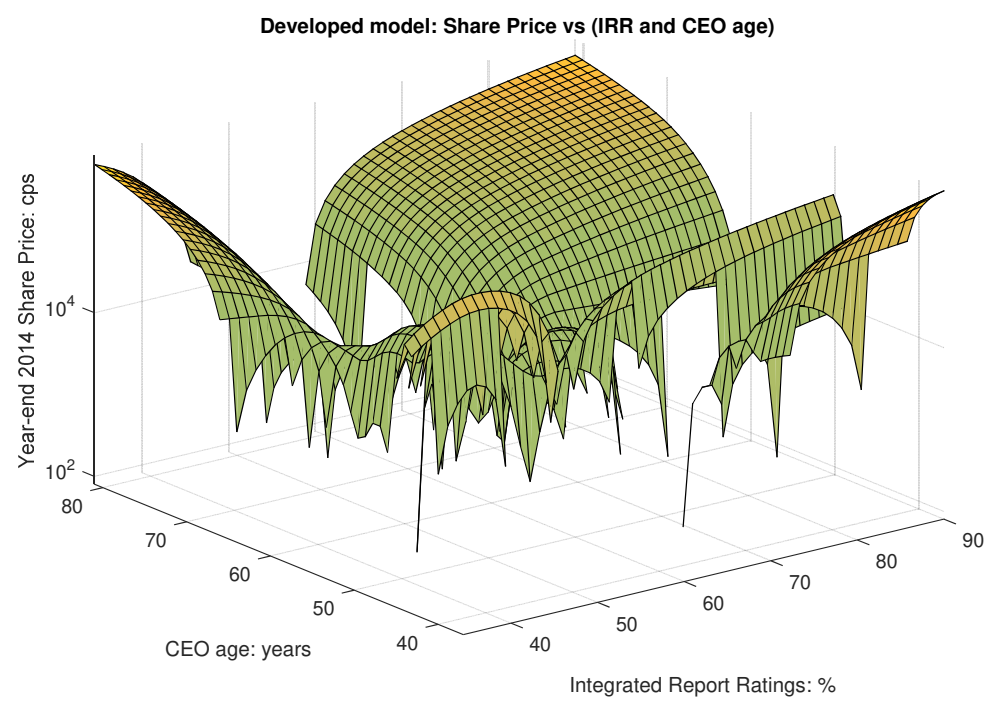

Fig. 7. Share price versus IRR \& CEO age: Top-106 JSE listed companies

As illustrated in Figure 7, as the age of the CEO increases so does the share price of the companies. More so, the few companies with the highest share price also have the oldest CEO in terms of age suggesting a correlation between the age of the CEO and the share price. The graph, however, narrows as it reaches its tipping point (see the left hand side of Figure 7) showing that very few companies have CEOs who are advanced in age (that is who are in their 80s).

As depicted in Figure 7, as the IRR increases, so does share price of these individual companies.
Most companies have a rating around the middle range (i.e., around $60-70 \%$ ) although the graph tapers off around the $90 \%$ (see the extreme right of Figure 7) showing that around the top 10 JSE listed companies have such a rating.

\section{Findings and discussion}

The findings of this study are reported in three components namely: IRR and share price, CEO's age and share price, and CEO's number of years as CEO and share price. These three components are articulated in subsequent sections of this findings section. 
7.1. IRR and share price. The study findings demonstrate that there is a positive correlation between IRR and the share price of the JSE listed companies. Companies that had high IRR also had higher share prices and those with low IRR had low share prices indicating the profound positive contribution of a long tradition of integrated corporate reporting (ICR) to the share price of the company. This finding is in consonance with Serafeim's (2014) study on the relationship between the practice of integrated reporting by US firms and the composition of investors (more dedicated investors and less transient investors). His study demonstrated that changes in ICR led to changes in investor base, while changes in investor base did not lead to changes in IR, supporting a causal effect of IR on investor base. Since investor base is often dependent on the share price, one can infer that positive changes in ICR, could lead to increased investor base owing to the favorability of the share price.

Our findings also buttresses Eccles, Ioannou, and Serafeim's (2012) findings that high sustainability companies (that is, companies that voluntarily adopted integrated sustainability policies) in the United States significantly outperformed their counterparts (that is, those that did not adopt ICR at all) in stock market, as well as accounting performance, over the long-term. Our inference from this finding is that companies with high IRR tend to generate more public trust and positive brand image to their stakeholders (for example, investors and financiers) and, hence, impact positively on their performance (for example, share price). This contradicts Rensburg and Botha's (2014) findings that the integrated reports do not contribute significantly to investors' decision-making processes. To the contrary, our findings gel well with the view that sustainable organizations (for example, those that practice and apply ICR diligently), which create value by combining a broad range of resources controlled by the organization or third parties generate positive outcomes for their shareholders or investors and society - outcomes instrumental in improving an organization's long-term financial performance (for example, their share price) (Ernest and Young Global, 2014).

The fact that a majority of the companies had IRR ratings within the middle upper range (i.e., around 60$70 \%$ ) demonstrates that these companies have comparative, moderately high ratings. In the South African context where the King III allowed a transition from "comply or explain" approach towards a 'apply or explain' regime founded on the need for an in-depth understanding of the practical application of the integrated sustainability reporting (ICR) principles and their motivations, the moderately high IRR for the majority of companies, perhaps, denotes this wider application of ICR including a comprehensive understanding of the benefits of such purposeful application by most companies. This findings resonates with observations in literature that, in view of the recent turmoil experienced in the South African financial services sector, it has become more important than ever to acknowledge that good reporting does not necessarily equate to good corporate behavior (King, 2014), but rather a deeper understanding of, willingness to internalize and demonstrate these corporate values (that is, "walking the talk").

Another finding on the IRR was that the graph tapered off around the $90 \%$ ceiling (see the extreme right of Figure 7) showing that around the top 10 companies have such a rating. This can be interpreted to mean that only the best companies with an established tradition of ICR manage to realize the top spot in IRR, demonstrating that a long duration is required for companies to master the art of integrated sustainability reporting. This findings corresponds to Eccles, Ioannou and Serafeim's (2012) findings on the comparative effect of corporate sustainability on organizational processes and performance of high sustainability US companies and low sustainability companies. Their findings revealed that high sustainability companies were more likely to have well established processes for stakeholder engagement and to exhibit higher disclosure of nonfinancial information than their low sustainability counterparts.

7.2. CEO age and share price. Our findings revealed a close positive relationship between age of the CEO and share price of companies. More so, the few companies with the highest share price also had the oldest CEO suggesting a correlation between the age of the CEO and the share price. The finding buttresses D'Ewart's (2015) co-relation analysis, which established that, while the 40 to 49 age range for CEO generated negative coefficients suggesting investors' interpretation of age as accumulated experience and development of business execution skills, the 50s to 60s age range for CEO generated positive coefficients, demonstrating that there exists a level of experience, measured via age, that markets believe CEOs need to generate a positive impact on firm returns. Our finding also coheres with the claim about the general correlation between the age of the CEO and his seniority (Ayed, 2014), which could influence the share price of a company positively.

The graph on CEO age-share price relationship, however, narrowed as it reaches its tipping point (see the left hand side of Figure 7) showing that very few companies had CEOs who were advanced in age (that is, in their 80s). Studies conducted by USA Today research suggest that among Standard \& Poor's 500 CEOs, 27 (5.4\%) were 47 and younger, and six (1.2\%) 
were 72 and older, indicating that there are very few CEOs who remain in command of large corporations at their advanced age. Since, in the South African context, the majority of CEO mainly assume their official responsibilities as CEOs at around thirty years, and the highest number of years as CEO is around 42 years, this means that these CEO perform at their highest with regard to share price when they are between $72-80$ years of age.

7.3. Years as CEO and share price. Our study revealed that there is a positive correlation between the CEO's number of years of experience (that is, years as CEO) and the share price of their respective companies. The few companies with the highest share price also had the CEOs with the longest careers serving as CEO, reflecting a correlation between years as CEO and the share price. It can be inferred that the more the CEO's years of experience, the higher their chances of improving company performance (for example, the share price). This finding resonates with the value-in specificity hypothesis, which emphasizes the positive effects of history dependent (for example, years as CEO) including context-specific experience of individuals (for example, type of industry experience, task-relevant experience) on company performance-themselves concern about level or depth of experience (Tian, 2008). Such value in specificity hypothesis emphasizes the historic/temporal patterns of experience accumulation such as board experience of a CEO (in terms of level and diversity), industrial experience (level and diversity), co-working experience and task experience (Tian, 2008) accumulated through years as CEO. Dikolli, Mayew and Nanda's (2011) study on the relationship between CEO tenure and performance-turnover demonstrated that surviving CEOs (that is, those who survive either the next quarter or ultimately their four-years of appointment) exhibit superior performance relative to CEOs who were, subsequently, dismissed, suggesting that CEO survival is associated with how performance mitigates uncertainty about corporate ability rather than (or in addition to) CEO entrenched power explanations. Although survival is not synonymous with age, the longer the CEO survives their consecutive terms, the more tenure translates into or mirrors the corporate experience of the CEO, with implications for company performance.

\section{Implications for future research}

Though commendable, the concentration of many companies' IRR ratings in the moderate upper range (that is, around $60-70 \%$ ) suggest that there is much room for improvement. Future studies should examine the critical success factors of the top tier (top ten) companies that have IRR of around $90 \%$ and compare them with those of the aforementioned middle range companies. This would allow these average performers to improve their upward mobility into the IRR of over $90 \%$.

The graph on CEO age-share price relationship illustrated that the few companies whose share price was at its highest had CEOs who were advanced in age (that is who are in their 80s). This implies that such companies can benefit from initiating the succession planning process earlier (that is, when the CEO is in his/her early 70s), to allow for the mentoring of younger blood in the organization in a bid to prevent a succession crisis. Future studies can examine the impact of such "shadowing" on firm performance.

The few companies with the highest share price also had the CEOs with longest careers serving as CEO suggesting a correlation between years as CEO and the share price. The absorptive capacity of such companies may need to be examined, as it relates to company performance, so that the success formula of such companies can be emulated by other companies.

\section{Conclusion}

In this study, we argued that the studies on ICR-firm performance, CEO age-firm performance, CEO's years of experience-firm performance tends to be distinct and run parallel to each other. As such, the current study identified the gap in mainstream literature as the paucity of studies that examined the combined influence of integrated thinking (in particular IRR), and internal firm capacities (especially CEO age, and years as CEO) on the performance (particularly the share price) of JSE listed companies. The study, therefore, explored the integrated influence of IRR, CEO age and years as CEO on the share price of 109 listed companies. The findings demonstrated that there is a positive relationship between each of these predictor variables and the share price of these companies. The findings also revealed a positive relationship between a combination of these variables and share price of companies.

Our findings, however, also demonstrated that there were a few companies (mainly the top ten companies) that had the highest IRR ratings indicating the importance of a long tradition of IRR in influencing the share price of companies. This means that the longer a company engaged in ICR, the greater the trust and confidence it generates from its stakeholders (investors, financiers, and suppliers), which positively influences the price of the company. The same study findings revealed that the older the CEO, the higher the share price of the company, hence, a positive corelation exists between the share price and the age of the CEO. The highest share price was recorded in companies with ageing CEO (that is, those in their 70s to $80 \mathrm{~s}$ ) insinuating that, in their mid to late $60 \mathrm{~s}$, these 
CEOs may need to prepare for their succession through shadowing younger CEOs who can take over from them. There were, however, very few companies with ageing CEO suggesting that even though ageing CEO were desirable for the share price, most companies were more at ease with younger CEOs.
Lastly, the study also demonstrated a positive correlation between years as CEO and the share price of the company reflecting that the former is associated with accumulated corporate experience. There were, nevertheless, few companies with CEOs with considerable years as CEOs.

\section{References}

1. Allgood, S. and Farrell, K.A. (2000). The Effect of CEO Tenure on the Relation between Firm Performance and Turnover. Finance Department Faculty Publications, Paper 22. Available at: http://digitalcommons.unl.edu/financefacpub/22.

2. Ayed, B. (2014). CEO characteristics and firm performance: Behavioral approach to governance. Available at: www.gredeg.cnrs.fr/Documents/2014/Ben_Ayed_2014.pdf.

3. Bowman Gilfillan Attorneys, B.G. (2009). Quick guide to corporate governance and King III. Sandton, Johannesburg. Available at: http://services.bowman.co.za/Brochures/OnlineServices/CorporateGovernance/Corporate-GovernanceKing-3.pdf.

4. Bhagat, S., Bolton, B. and Subramanian, A. (2011). Director Notes: Does CEO Education Matter? The Conference Board, United States.

5. Buritt, L.B. (2012). Environmental performance accountability: plane, people, profits, Accounting, Auditing and Accountability Journal, 25 (2), pp. 370-405.

6. Carroll, A.B. \& Shabana, K.M. (2010). The business case for corporate social responsibility: A review of concepts, research and practice, International Journal of Management Review, 12 (1), pp. 85-105.

7. C'imerov'a, H. (2012). The Influence of CEO Experience and Education on Firm Policies. Nova School of Business and Economics, November 2012.

8. Dekker Attorneys. (2002). King Report on Corporate Governance for South Africa: What it means to you. Available at: www.cliffedekker.com.

9. De Klerk, M. \& De Villiers, C. (2012). The value relevance of corporate responsibility reporting: South African evidence, Meditari Accountancy Research, 20 (1), pp. 21-38.

10. D'Ewart, B.H. (2015). The effect of CEO gender, age, and salary on firm value. CMC Senior Theses. Paper 1059. Available at: http://scholarship.claremont.edu/cmc theses/1059.

11. Deysel, B. \& Kruger, J. (2015). The relationship between South African CEO compensation and company performance in the banking industry, Southern African Business Review, 19 (1), pp. 137-169.

12. Dherment-Ferere, I. and Renneboog, L. (2000). Share Price Reactions to CEO Resignations and Large Shareholder Monitoring in Listed French Companies. Department of Finance and Center for Economic Research, Tilburg University.

13. Dikolli, S., Mayew, W. and Nanda, D. (2011). CEO Tenure and the Performance-Turnover Relation. Durham, North Carolina.

14. Eccles, R., Ioannou, I. and Serafeim, G. (2014). The Impact of Corporate Sustainability on Organizational Processes and Performance, Management Science, forthcoming.

15. Eccles, R. and Serafeim, G. (2014). Corporate and Integrated Reporting: A Functional perspective. Harvard Business School, Working Paper 14-094, May 5, 2014.

16. Eccles, R., Ioannou, I. and Serafeim, G. (2012). The Impact of Corporate Sustainability on Organizational Processes and Performance. NBER Working Paper No. 17950, Issued in March 2012.

17. Enerst and Young Global. (2014). Integrated reporting: Elevating value. UK: Ernst and Young Global Limited.

18. Friedman, J.H (1991). Multivariate Adaptive Regression Splines (with discussion), The Annals of Statistics, 19 (1), pp. 1-67.

19. Friedman, J.H. (1993). Fast MARS. California: Stanford University.

20. Hassel, L., Nilsson, H. \& Nyquist, S. (2005). The value relevance of environmental performance, European Accounting Review, 14 (1), pp. 41-61.

21. Hudson, J., Jeaneau, H. and Zlotnicka, E. (2012). Q-Series ${ }^{\circledR}$ : What is "Integrated Reporting"? UBS Investment Research. 20 June 2012. Available at: www.ubs.com/investmentresearch.

22. Institute of Directors in Southern Africa. (2009). King Code of Governance for South Africa 2009. Institute of Directors in Southern Africa.

23. International Integrated Reporting Committee (IIRC). (2011). Towards Integrated Reporting: Communicating Value in the 21st Century, London.

24. Jones, D. (2008). Does age matter when you're CEO? Available at: http://usatoday30.usatoday.com/money/companies/ management/2008-08-12-obama-mccain-age-ceos_N.htm.

25. Khan, W. and Vieito, J. (2013). CEO gender and firm performance, Journal of Economics and Business, 67, pp. 55-66.

26. The King Report. (1994). The King Report on Corporate Governance (The Institute of Directors in South Africa).

27. The King Report ('King II'). (2002). The King Report on Corporate Governance for South Africa (Parktown: King Committee on Corporate Governance, Institute of Directors in Southern Africa).

28. The King Report ('King III'). (2009). King Report on Governance for South Africa. Institute of Directors in Southern Africa. 
29. King, M. (2011). Above all, integrated reporting is about good business. In: International Integrated Reporting Committee (IIRC). Towards integrated reporting: Communicating Value in the 21st Century. Available at: www.theiirc.org.

30. King, M. (2014). Forward. In: Value creation-The journey continues a survey of JSE Top-40 companies' integrated reports. PricewaterhouseCoopers.

31. KPMG International Cooperative. (2011). Integrated Reporting Performance insight through Better Business Reporting, Issue 1, KPMG International Cooperative, Switzerland.

32. Marcia, A., Maroun, W. and Callaghan, C. (2015). Value relevance and corporate responsibility reporting in the South African context: An alternate view post King-III, South African Journal of Economic and Management Sciences, 18 (4), pp. 500-518.

33. Nulla, Y. (2013). The Empirical Study of the Relationship between CEO Cash Compensation and CEO Power in American Companies, Journal of Marketing Management, 1 (1), pp. 1-12.

34. PricewaterhouseCoopers (PWC) Integrated Report. (2014). Value creation: The journey continues - A survey of JSE Top-40 companies' integrated reports. An analysis of company reporting in terms of the IIRC's International $<$ IR $>$ Framework. South Africa.

35. Rensburg, R. and Botha, E. (2014). Is integrated reporting the silver bullet of financial communication? A stakeholder perspective from South Africa, Public Relations Review, 40 (2), pp. 144-152.

36. Serafeim, G. (2014). Integrated Reporting and Investor Clientele, Journal of Applied Corporate Finance, 27 (2), pp. 34-51.

37. Sisodia, R.S. (2009). Doing business in the age of conscious capitalism, Journal of Indian Business Research, 1 (2/3), pp. 188-192.

38. Smith, N., Smith, V. and Verner, M. (2005). Do Women in top management affect firm performance? A Panel Study of 2500 Danish firms. Discussion Papers Series, IZA DP No. 1708, Institute for the Study of Labor, August 2005.

39. Solomon, J. and Maroun, W. (2012). Integrated reporting: the influence of King III on social, ethical and environmental reporting. The Association of Chartered Certified Accountants, London, 2012.

40. Serfling, M. (2013). CEO Age and the Riskiness of Corporate Policies, Journal of Corporate Finance, Forthcoming, December 11, 2013. http://dx.doi.org/10.2139/ssrn.2158973.

41. Steyn, M. (2014). Senior executives' perspectives of integrated reporting regulatory regimes as a mechanism for advancing sustainability in South African listed companies, Southern African Business Review, 18(3), pp. $142-174$.

42. The Association of Chartered Certified Accountants. (2012). Integrated reporting: the influence of King III on social, ethical and environmental reporting. London, 2012.

43. The South African Institute of Chartered Accountants. (2009). The birth of integrated reporting for companies. Posted Oct 2009. Available at: https://www.saica.co.za/News/NewsArticlesandPressmediareleases/tabid/695/ itemid/1908/pageid/3/language/en-ZA/language/en-ZA/Default.aspx

44. Tian, J. (2008). CEO Selection performance: Does board experience matter? PhD Thesis, University of Southern California.

45. Tukey, J.W. (1977). Exploratory Data Analysis. New York: Addison-Wesley.

46. Vintilă, G. and Gherghina, S. (2012). An Empirical Investigation of the Relationship between Corporate Governance Mechanisms, CEO Characteristics and Listed Companies' Performance, International Business Research, 5 (10), pp. 175-191.

\section{Appendix}

Appendix A: Top 106 JSE listed companies' information

\begin{tabular}{|l|l|l|c|c|c|c|}
\hline \multicolumn{1}{|c|}{$\begin{array}{c}\text { JSE } \\
\text { symbol }\end{array}$} & \multicolumn{1}{|c|}{ Company name } & \multicolumn{1}{|c|}{ Industry } & $\begin{array}{c}\text { Year-end 2014 share } \\
\text { price: cps }\end{array}$ & $\begin{array}{c}\text { Year-end 2014 } \\
\text { ratings }\end{array}$ & CEO age & Years as CEO \\
\hline TSH & Tsogo Sun Holdings Limited & Consumer Services & 2900 & $\mathrm{~A}$ & 40 & 3.2 \\
\hline RBP & Royal Bafokeng Platinum Limited & Basic Materials & 2200 & $\mathrm{~A}$ & 58 & 4.7 \\
\hline ACL & ArcelorMittal South Africa Limited & Basic Materials & 2641 & $\mathrm{~A}$ & 51 & 0.5 \\
\hline NED & Nedbank Group Limited & Financials & 24900 & $\mathrm{~A}$ & 48 & 4.8 \\
\hline LBH & Liberty Holdings Limited & Financials & 12269 & $\mathrm{~A}$ & 44 & 0.8 \\
\hline NPK & Nampak Limited & Industrials & 4362 & $\mathrm{~A}$ & 45 & 0.7 \\
\hline RDF & Redefine Properties Limited & Financials & 1070 & $\mathrm{~A}$ & 45 & 0.4 \\
\hline PPC & Pretoria Portland Cement Limited & Industrials & 1490 & $\mathrm{~A}$ & 46 & 0 \\
\hline SLM & Sanlam Limited & Financials & 7000 & $\mathrm{~A}$ & 58 & 11.7 \\
\hline SOL & Sasol Limited & Oil \& Gas & 43101 & $\mathrm{~A}$ & 52 & 3.5 \\
\hline BAW & Barloworld Limited & Industrials & 9574 & $\mathrm{~A}$ & 48 & 8 \\
\hline AMS & Anglo American Platinum Limited & Basic Materials & 34112 & $\mathrm{~A}$ & 49 & 2.3 \\
\hline LHC & Life Healthcare Group Holdings Limited & Healthcare & 4276 & $\mathrm{~A}$ & 49 & 0.7 \\
\hline WBO & Wilson Bayly Holmes-Ovcon & Industrials & 8947 & $\mathrm{~A}$ & 53 & 6 \\
\hline GFI & Gold Fields Limited & Basic Materials & 5231 & $\mathrm{~A}$ & 56 & 6.6 \\
\hline EXX & Exxaro Resources & Basic Materials & 10350 & $\mathrm{~B}$ & 60 & 7.3 \\
\hline
\end{tabular}


Appendix A (cont.): Top 106 JSE listed companies' information

\begin{tabular}{|c|c|c|c|c|c|c|}
\hline $\begin{array}{c}\text { JSE } \\
\text { symbol }\end{array}$ & Company name & Industry & $\begin{array}{c}\text { Year-end } 2014 \text { share } \\
\text { price: cps }\end{array}$ & $\begin{array}{l}\text { Year-end } 2014 \\
\text { ratings }\end{array}$ & CEO age & Years as CEO \\
\hline $\mathrm{KIO}$ & Kumba Iron Ore Limited & Basic Materials & 23990 & $B$ & 55 & 2.9 \\
\hline TON & Tongaat Hulett Limited & Consumer Goods & 17292 & B & 62 & 12.6 \\
\hline $\mathrm{NHM}$ & Northam Platinum Limited & Basic Materials & 3670 & $\mathrm{~B}$ & 51 & 0.8 \\
\hline SNT & Santam Limited & Financials & 21500 & B & 57 & 7.5 \\
\hline WHL & Woolworths Holdings & Consumer Services & 7710 & $\mathrm{~B}$ & 55 & 4.1 \\
\hline AGL & Anglo American PLC & Basic Materials & 21533 & B & 56 & 1.7 \\
\hline GND & Grindrod Limited & Industrials & 2240 & $B$ & 54 & 8 \\
\hline MPT & Mpact Ltd & Industrials & 3251 & $\mathrm{~B}$ & 45 & 5 \\
\hline OCE & Oceana Group Limited & Consumer Goods & 10486 & $\mathrm{~B}$ & 45 & 5.5 \\
\hline SAP & Sappi Limited & Basic Materials & 4220 & $\mathrm{~B}$ & 46 & 0.5 \\
\hline AFEP & AECI Limited & Basic Materials & 13382 & B & 53 & 1.8 \\
\hline$A E G$ & Aveng Group Limited & Industrials & 251 & $\mathrm{~B}$ & 47 & 0.8 \\
\hline ANG & AngloGold Ashanti Limited & Basic Materials & 10170 & $\mathrm{~B}$ & 48 & 1.6 \\
\hline SGL & Sibanye Gold Limited & Basic Materials & 2255 & $\mathrm{~B}$ & 55 & 2 \\
\hline VOD & Vodacom Group Limited & Telecommunications & 12843 & $B$ & 43 & 2.3 \\
\hline TFG & The Foschini Group Limited & Consumer Services & 13324 & B & 57 & 7 \\
\hline TRU & Truworths International Limited & Consumer Services & 7728 & $\mathrm{~B}$ & 62 & 23.5 \\
\hline AFX & African Oxygen Limited & Basic Materials & 1577 & $\mathrm{~B}$ & 48 & 0 \\
\hline HYP & Hyprop Investments & Financials & 9750 & $\mathrm{~B}$ & 65 & 3.6 \\
\hline MND & Mondi Limited & Basic Materials & 18963 & $B$ & 52 & 7.6 \\
\hline MNP & Mondi PLC & Basic Materials & 18950 & $\mathrm{~B}$ & 52 & 7.6 \\
\hline SBK & Standard Bank Group Limited & Financials & 14348 & B & 55 & 1.8 \\
\hline $\mathrm{BGA}$ & Barclays Africa Group Limited & Financials & 18200 & $\mathrm{~B}$ & 55 & 5.8 \\
\hline SUI & Sun International Limited & Consumer Services & 12890 & $\mathrm{~B}$ & 51 & 1.9 \\
\hline MUR & Murray \& Roberts Holdings Limited & Industrials & 2081 & $\mathrm{~B}$ & 55 & 3 \\
\hline TKG & Telkom SA SOC & Telecommunications & 7000 & $\mathrm{~B}$ & 45 & 1.7 \\
\hline APN & Aspen Pharmacare Holdings Limited & Healthcare & 40600 & C & 50 & 18 \\
\hline MDC & Mediclinic International Limited & Healthcare & 10065 & C & 58 & 4.7 \\
\hline SHF & Steinhoff International Holdings Limited & Consumer Goods & 5940 & C & 53 & 17 \\
\hline HAR & Harmony Gold Mining Company Limited & Basic Materials & 2003 & C & 43 & 6 \\
\hline ILV & Illovo Sugar Limited & Consumer Goods & 2450 & C & 48 & 1.3 \\
\hline BIL & BHP Billiton PLC & Basic Materials & 24868 & C & 58 & 1.6 \\
\hline IPL & Imperial Holdings Limited & Industrials & 18500 & C & 64 & 0.8 \\
\hline JDG & JD Group Limited & Consumer Services & 2435 & $\mathrm{C}$ & 51 & 0.7 \\
\hline OML & Old Mutual PLC & Financials & 3470 & $\mathrm{C}$ & 57 & 6.3 \\
\hline LON & Lonmin PLC & Basic Materials & 3162 & $\mathrm{C}$ & 47 & 1.5 \\
\hline BVT & Bidvest Group Limited & Industrials & 30388 & $\mathrm{C}$ & 67 & 17 \\
\hline CPF & Capital Property Fund Limited & Financials & 1342 & C & 57 & 3.6 \\
\hline MRP & Mr Price Group Limited & Consumer Services & 23500 & C & 54 & 4.4 \\
\hline PFG & Pioneer Food Group Limited & Consumer Goods & 14300 & C & 48 & 1.7 \\
\hline ARI & African Rainbow Minerals Limited & Basic Materials & 11900 & $\mathrm{C}$ & 55 & 2.8 \\
\hline AEL & Allied Electronics Corporation Limited & Industrials & 1619 & C & 54 & 13 \\
\hline $\mathrm{BCX}$ & Business Connexion Group Limited & Technology & 615 & C & 41 & 0.5 \\
\hline INP & Investec PLC and Investec Limited & Financials & 9773 & C & 63 & 18 \\
\hline OMN & Omnia Holdings Limited & Basic Materials & 18100 & $\mathrm{C}$ & 57 & 16 \\
\hline RLO & Reunert Limited & Industrials & 6070 & $\mathrm{C}$ & 44 & 0.2 \\
\hline IMP & Impala Platinum Holdings Limited & Basic Materials & 7578 & $\mathrm{D}$ & 55 & 2.6 \\
\hline $\mathrm{CML}$ & Coronation Fund Managers Limited & Financials & 11516 & $\mathrm{D}$ & 45 & 1.9 \\
\hline ITU & Intu Properties plc & Financials & 6044 & $\mathrm{D}$ & 56 & 13.8 \\
\hline $\mathrm{SAB}$ & SABMiller PLC & Consumer Goods & 60539 & $\mathrm{D}$ & 55 & 1.7 \\
\hline MMI & MMI Holdings Limited & Financials & 3000 & $\mathrm{D}$ & 46 & 4.1 \\
\hline BAT & Brait SE & Financials & 7870 & $\mathrm{D}$ & 49 & 3.8 \\
\hline FBR & Famous Brands Limited & Consumer Services & 11536 & $\mathrm{D}$ & 61 & 4.6 \\
\hline FSR & FirstRand Limited & Financials & 5057 & $\mathrm{D}$ & 57 & 5 \\
\hline
\end{tabular}


Appendix A (cont.): Top 106 JSE listed companies' information

\begin{tabular}{|c|c|c|c|c|c|c|}
\hline \begin{tabular}{|c|} 
JSE \\
symbol
\end{tabular} & Company name & Industry & $\begin{array}{l}\text { Year-end } 2014 \text { share } \\
\text { price: cps }\end{array}$ & $\begin{array}{l}\text { Year-end } 2014 \\
\text { ratings }\end{array}$ & CEO age & Years as CEO \\
\hline JSE & JSE Limited & Financials & 12100 & $D$ & 48 & 3 \\
\hline $\mathrm{ADH}$ & AdvTech Limited & Financials & 883 & $\mathrm{D}$ & 56 & 0 \\
\hline $\mathrm{BTI}$ & British American Tobacco PLC & Consumer Goods & 63200 & $\mathrm{D}$ & 58 & 3.8 \\
\hline $\mathrm{CPI}$ & Capitec Bank Holdings Limited & Financials & 34000 & $\mathrm{D}$ & 50 & 1 \\
\hline KAP & KAP Industrial Holdings & Industrials & 490 & $\mathrm{D}$ & 65 & 2.7 \\
\hline CLS & Clicks Group Limited & Consumer Services & 8100 & $\mathrm{D}$ & 60 & 9 \\
\hline MSM & Massmart Holdings Limited & Consumer Services & 14280 & D & 49 & 0.6 \\
\hline $\mathrm{RMH}$ & RMB Holdings Limited & Financials & 6434 & $\mathrm{D}$ & 45 & 0.7 \\
\hline TBS & Tiger Brands Limited & Consumer Goods & 36806 & $\mathrm{D}$ & 54 & 6.9 \\
\hline DSY & Discovery Limited & Financials & 11140 & $E$ & 50 & 23 \\
\hline GRT & Growthpoint Properties Limited & Financials & 2749 & $E$ & 50 & 10.3 \\
\hline NPN & Naspers Limited & Consumer Services & 151512 & $E$ & 41 & 0.7 \\
\hline NTC & Netcare Limited & Healthcare & 3795 & $\mathrm{E}$ & 53 & 9.3 \\
\hline $\mathrm{RCL}$ & RCL Foods Limited & Consumer Goods & 1940 & $\mathrm{E}$ & 58 & 11.9 \\
\hline SPP & The Spar Group Limited & Consumer Services & 16136 & $E$ & 58 & 0.9 \\
\hline $\mathrm{EOH}$ & EOH Holdings Ltd. & Technology & 10857 & $\mathrm{E}$ & 62 & 17 \\
\hline $\mathrm{CCO}$ & Capital \& Counties Properties PLC & Financials & 6600 & $E$ & 48 & 8.3 \\
\hline PIK & Pick N Pay Stores Limited & Consumer Services & 5262 & $E$ & 53 & 1.9 \\
\hline RPL & Redefine International PLC & Financials & 985 & $\mathrm{E}$ & 55 & 1.1 \\
\hline ASR & Assore Ltd & Basic Materials & 14965 & $\mathrm{E}$ & 63 & 10.6 \\
\hline IVT & Invicta Holdings & Industrials & 9801 & $E$ & 53 & 14 \\
\hline RES & Resilient REIT Limited & Financials & 8399 & $\mathrm{E}$ & 53 & 12.5 \\
\hline $\mathrm{AVI}$ & AVI Limited & Consumer Goods & 7810 & $\mathrm{E}$ & 51 & 9.2 \\
\hline DTC & Datatec Limited & Technology & 5570 & $\mathrm{E}$ & 52 & 28.9 \\
\hline REM & Remgro Limited & Industrials & 25399 & $\mathrm{E}$ & 48 & 2.6 \\
\hline LEW & Lewis Group Limited & Consumer Services & 7650 & $\mathrm{E}$ & 41 & 5 \\
\hline RMI & Rand Merchant Insurance Holdings Limited & Financials & 4054 & $\mathrm{E}$ & 45 & 0.75 \\
\hline TRE & Trencor Limited & Industrials & 7040 & $\mathrm{E}$ & 81 & 42 \\
\hline ATT & Attacq Limited & Financials & 2200 & $\mathrm{~F}$ & 43 & 3.5 \\
\hline AIP & Adcock Ingram Holdings Limited & Healthcare & 4805 & $\mathrm{~F}$ & 54 & 0.75 \\
\hline $\mathrm{HCl}$ & Hosken Consolidated Investments Limited & Financials & 14900 & $\mathrm{~F}$ & 64 & 18 \\
\hline NEP & New Europe Property Investiments PLC & Financials & 11400 & $\mathrm{~F}$ & 43 & 7.2 \\
\hline REI & Reinet Investments S.C.A. & Financials & 2526 & $\mathrm{~F}$ & 62 & 2.9 \\
\hline PSG & PSG Group Limited & Financials & 12775 & $\mathrm{~F}$ & 37 & 4.6 \\
\hline CFR & Compagnie Financiere Richemont SA & Consumer Goods & 10453 & $\mathrm{~F}$ & 62 & 10 \\
\hline SHP & Shoprite Holdings & Consumer Services & 16824 & $\mathrm{~F}$ & 69 & 36 \\
\hline
\end{tabular}

